\title{
An immunohistochemical study of the distribution of $p 16$ protein in oral mucosa in smokers, non-smokers and in frictional keratosis
}

\author{
Bassel Tarakji ${ }^{1}$, Omar Kujan ${ }^{2}$, Mohammad Z Nassani ${ }^{3}$ \\ ${ }^{1}$ Head of Department of Oral Pathology, Faculty of Dentistry, Aleppo University, Aleppo, Syria \\ ${ }^{2}$ Department of Oral Pathology and Medicine, Faculty of Dentistry, Al-Baath University, Hama, Syria \\ ${ }^{3}$ Faculty of Dentistry, Aleppo University, Aleppo, Syria
}

\author{
Correspondence: \\ Department of Oral Pathology \\ Faculty of Dentistry \\ Aleppo University \\ Aleppo, Syria \\ denpol@yahoo.co.uk
}

Received: 13/03/2009

Accepted: $21 / 02 / 2010$

\author{
Tarakji B, Kujan O, Nassani MZ. An immunohistochemical study of \\ the distribution of $\mathrm{p} 16$ protein in oral mucosa in smokers, non-smokers \\ and in frictional keratosis. Med Oral Patol Oral Cir Bucal. 2010 Sep 1;15 \\ (5):e681-4. \\ http://www.medicinaoral.com/medoralfree01/v15i5/medoralv15i5p681.pdf

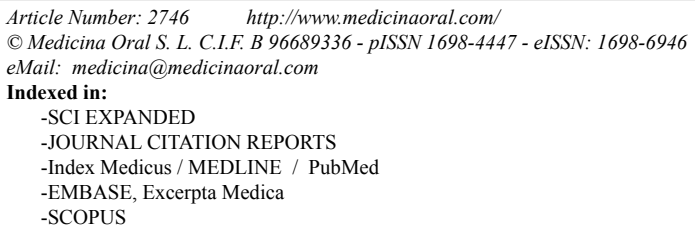

\begin{abstract}
Objective: Our study aimed to characterize alteration in the immunohistochemical p16 expression in normal oral mucosa and non-neoplastic hyperproliferative disorders (i.e. frictional keratosis and mucosa from smokers).

Study design: 43 specimen of oral mucosa were examined using immunohistochemistry.

Results: In normal mucosa, there was strong positive nuclear staining in a proportion of fibroblasts and endothelial cells in the lamina propria, with variable expression in nuclei of the epithelial layer. However, when the patient's tobacco smoking was examined, p16 nuclear staining in oral epithelium was seen in 4/20 (20\%) of smokers and $0 / 23(0 \%)$ of non-smokers. In every case of frictional keratosis $(n=11)$, there was strong nuclear staining of some basal and supra-basal cells. In addition, there was strong nuclear staining of parakeratinizing squamous in a band above the spinous layer. In clinically normal oral epithelium of smokers and in frictional keratosis, basal and supra-basal cells expressed strong p16 nuclear staining which was absent in the control tissue examined.

Conclusion: Our data suggest that p16 expression may be involved in the long-term loss of proliferation in cell senescence of oral mucosa.
\end{abstract}

Key words: Immunohistochemical, p 16, oral mucosa, smokers, frictional keratosis. 


\section{Introduction}

The protein, p16 is a negative regulator of the cell cycle and is the product of the cyclin-dependent kinase 2 (CDKN2) gene. Studies of the molecular genetics of oral cancer have shown that the CDKN2 gene is frequently inactivated by methylation or homozygous deletion (1). Numerous imunohistochemical studies have also shown loss of p16 expression in malignant squamous cells in head and neck (1-3). Lai and El-Naggar (4) have reported the presence of p16 protein in normal oral mucosa by Western blotting. In addition, Nielsen et al. (5) described the distribution of p16 protein in a large range of normal human tissues and that although staining was present in many tissues including salivary gland, it was absent in epidermis. Normal oral mucosa was not included in that study and many investigators who have used immunohistochemistry to evaluate p16 status in oral squamous cell carcinomas and pre-malignant lesions have used frequently stromal cells rather than normal oral epithelium as a control tissue.

As p16 is involved in cell cycle regulation its expression may vary with cell turnover times in the oral mucosa which have been shown to be variable in different types of oral mucosa (6). Alterations in the expression of the other tumour suppressor gene proteins such as $\mathrm{p} 53$ have been reported in smokers (7) and in conditions where cell turnover is increased such as frictional keratosis (8). The aim of the present study was to investigate the distribution of p16 staining in normal lining, masticatory and specialized oral mucosa and in non-neoplastic hyperproliferative disorders.

\section{Materials and Methods}

Clinically normal human oral mucosa was obtained by biopsy under local anesthesia. Tissue was obtained from a bank of health status defined volunteers, redundant surgical flaps and biopsies submitted to the oral pathology service, which included normal oral mucosa adjacent to non-inflammatory and non-neoplastic lesions. A smoking history was available in each case. No additional demographic data were collected. Tissue was immediately placed into $10 \%$ neutral buffered formalin, fixed for 24 hours and processed into paraffin wax. Sections were prepared at $4 \mu \mathrm{m}$ and stained by the haematoxylin and eosin method. All specimens were examined by two oral pathologists and any morphologically abnormal tissues were excluded. Normal tissues examined included floor of mouth, ventral tongue, hard palate, buccal mucosa, gingival, labial mucosa and soft palate (Table 1). Eleven cases of frictional keratosis involving the buccal mucosa or lateral tongue were also included.

An optimization process using sections of normal human tissue was done for immunohistochemistry standardization. A mouse monoclonal antibody to p16, (F-12,
Santa Cruz biotechnology,USA) was employed diluted to $4 \mu \mathrm{g} / \mathrm{ml}$ in Tris buffered saline (TBS) containing $0.1 \%$ bovine serum albumin at $\mathrm{pH}$ 7.6. Endogenous peroxidase activity was quenched with $3 \%$ hydrogen peroxide in distilled water. Antigen retrieval was performed with $0.1 \%$ trypsin in calcium chloride $\mathrm{pH} 7.8$ at $37^{\prime} \mathrm{C}$ for 20 minutes. Sections were incubated with p16 antibody for 1 hour at room temperature. After washing in TBS labeling was undertaken using the Streptavidin-Biotin duet kit (Dako ${ }$, Denmark), using diaminobenzidine as the chromogen. Methyl green counterstain was used. Positive controls used were two blocks of separate normal human submandibular glands, which had been removed as part of a surgical prophylactic neck dissection procedures (5). Negative controls were performed by substitution of the antibody step by TBS.

Local research ethics committee provided a favourable ethics opinion (North Manchester LREC study number 02/104).

\section{Results}

\section{Normal oral mucosa}

In all 43 specimens examined there was strong positive nuclear staining in a proportion of fibroblasts and endothelial cells in the lamina propria. Where minor salivary glands were present, ductal cell nuclei were always strongly stained. The oral epithelium was variably stained with some cases showing nuclear expression in occasional basal and supra-basal cells, whilst in others there was no nuclear staining (Table 1). In some cases there was strong cytoplasmic expression in the oral epithelium. P16 nuclear staining in oral epithelium was seen in 4/20(20\%) of smokers (Fig. 1A) and 0/23 (0\%) of non-smokers (Table 2); (Fig. 1B). Cytoplasmic staining was present in $9 / 20(45 \%)$ of smokers and $8 / 23(35 \%)$ of non-smokers, and is doubt significance.

Pearson Chi-square test showed that there was a significant difference in nuclear staining between smokers and non-smokers (chi-square $=5.07, \mathrm{df}=1, \mathrm{p}=0.024$ ). There was no significant difference in the cytoplasmic staining (chi-square $=0.467, \mathrm{df}=1, \mathrm{p}=0.494$ ) between smokers and non-smokers.

Frictional keratosis $(n=11)$

In haematoxylin and eosin stained sections there was irregular hyperparakeratosis and variable acanthosis. In every case there was strong nuclear staining in a proportion of fibroblasts and endothelial cells in the lamina propria. Within oral epithelium there was strong nuclear staining of some basal and supra-basal cells in every case and variable cytoplasmic staining in 3/11 cases. In addition there was strong nuclear staining of parakeratinizing squames in a band above the spinous layer in every case. 
Table 1. Shows the pattern of p16 expression at various oral sites.

\begin{tabular}{|c|c|c|c|c|c|c|c|c|}
\hline & \multicolumn{2}{|c|}{ Nuclear staining } & \multicolumn{2}{|c|}{ Cytoplasmic staining } & \multicolumn{2}{|c|}{$\begin{array}{c}\text { Nuclear and cytoplasmic } \\
\text { taining }\end{array}$} & \multicolumn{2}{|c|}{ No staining } \\
\hline & Smoker & $\begin{array}{l}\text { Non- } \\
\text { smoker }\end{array}$ & Smoker & $\begin{array}{l}\text { Non- } \\
\text { smoker }\end{array}$ & Smoker & Non-smoker & Smoker & $\begin{array}{l}\text { Non- } \\
\text { smoker }\end{array}$ \\
\hline $\begin{array}{l}\text { Ventral tongue/ } \\
\text { Floor of mouth }\end{array}$ & 2 & 0 & 3 & 2 & 1 & 0 & 1 & 0 \\
\hline Buccal mucosa & 0 & 0 & 2 & 0 & 1 & 0 & 2 & 7 \\
\hline Labial mucosa & 0 & 0 & 2 & 3 & 0 & 0 & 1 & 2 \\
\hline Hard palate & 2 & 0 & 2 & 1 & 0 & 0 & 2 & 4 \\
\hline Soft palate & 0 & 0 & 0 & 2 & 0 & 0 & 1 & 2 \\
\hline
\end{tabular}

Table 2. Expression of p16 in smokers and non-smokers.

\begin{tabular}{|c|c|c|c|c|c|}
\hline & $\begin{array}{c}\text { Nuclear and } \\
\text { Cytoplasmic staining }\end{array}$ & $\begin{array}{c}\text { Nuclear } \\
\text { staining }\end{array}$ & $\begin{array}{c}\text { Cytoplasmic } \\
\text { staining }\end{array}$ & No staining & $\begin{array}{c}\text { Total } \\
\text { number }\end{array}$ \\
\hline Smokers & 2 & 4 & 9 & 7 & 20 \\
\hline Non-smokers & 0 & 0 & 8 & 15 & 23 \\
\hline
\end{tabular}

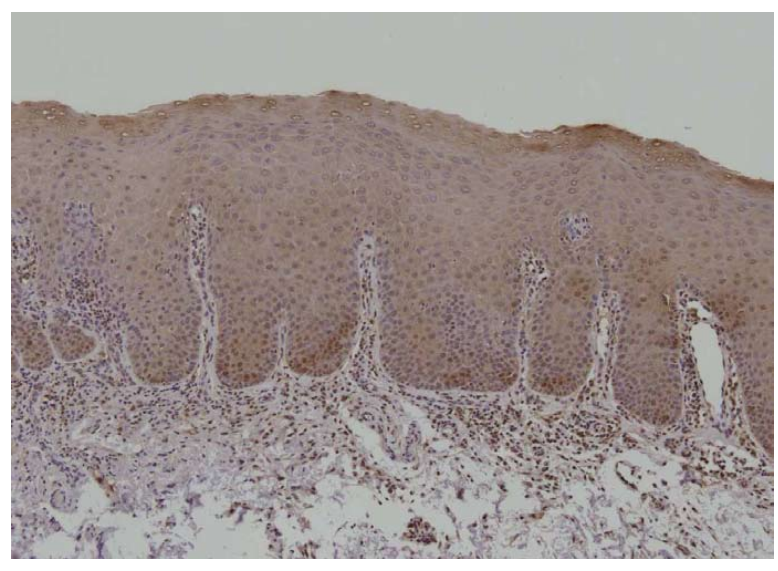

Fig. 1A. p16 positive immunostaining of a section of buccal mucosa from a smoker $(\times 200)$.

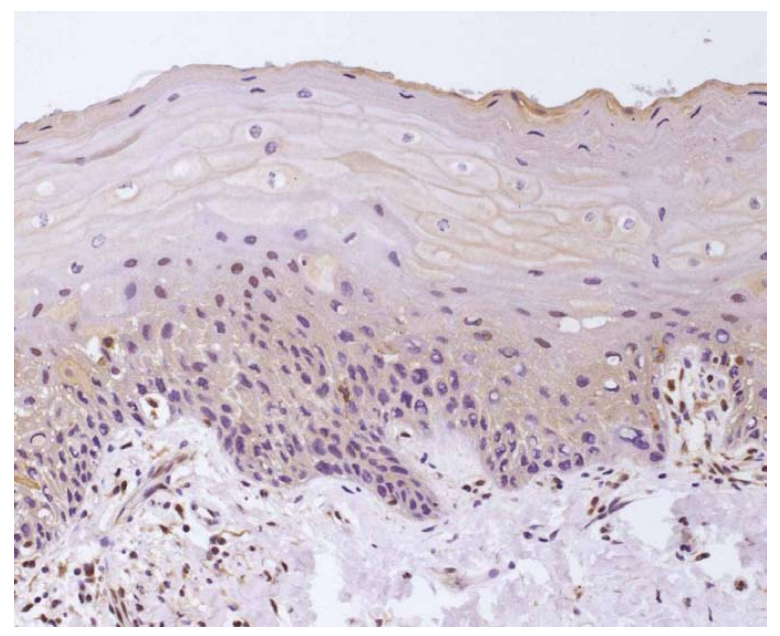

Fig. 1B. Negative immunostaining of a section of buccal mucosa from non smoker. Note the p16 positive staining in the stromal cells $(\times 400)$.

\section{Discussion}

We have shown that in the clinically normal oral epithelium of smokers, basal and supra-basal cells expressed strong p16 nuclear staining, whereas in non-smokers these nuclei were unstained. P16 is involved in cell cycle regulation and its expression is therefore influenced by cell turnover. Nicotine, a component of tobacco smoke, is known to significantly stimulate cell growth. Epithelial cell DNA synthesis and cell proliferation was stimulated at nicotine concentrations lower than those obtained in blood after smoking (9). Nicotine also stimulated the proliferation of a proportion of human cervical cells in vitro (10). In the present study nuclear expression of p16 was seen in smokers in $20 \%$ of clinically oral normal epithelial suggesting that smoking may lead to an increase of this cell cycle control protein. The cell cycle regulatory protein p16 is encoded by the CDKN2A gene on chromosome $9 \mathrm{p} 21$. Binding of p16 to CDK4 and CDK6 prevents their interaction with cyclin D molecules. CDK-cyclin complexes inactivate the retinoblastoma-associated gene product ( $\mathrm{pRb}$ ) thus encouraging the cell to pass the G1-S phase of the cell cycle.

The effect of enhanced p16 expression may be to slow the stimulated growth of oral mucosal cells, as upregulation of p16 is known to cause growth arrest of cells, for example melanocytes irradiated with ultra-violet $\mathrm{B}$ irradiation (11).

Cell cycle-associated proteins, p16 and p53, are important in regulating the G1-S checkpoint in the cell cycle, and their functional alteration plays a key role in cell proliferation. Although smokers' and frictional keratosis are non-neoplastic hyperproliferative disorders, 
abnormalities of p16 protein expression are closely associated with the esophageal carcinomas (12) and carcinomas arising in pleomorphic salivary adenoma, where homozygous deletion of the p16 gene has been shown to be present (13).

Nielsen et al. (5) found that p16 expression in normal tissues occurs in a highly restricted pattern, which surprisingly does not appear to correlate with cell turnover. They found that esophageal squamous epithelium and tonsillar crypt epithelium showed strong nuclear staining, whereas epidermis showed only occasional positive cell staining. The present results demonstrated that normal oral epithelium in non-smokers does not express p16 at the immunohistochemical level. Chen et al. (14) have indicated that methylation of the p16INK4a promoter may play a potential role in the pathogenesis of psoriasis. Nuclear p16 protein is detectable by immunohistochemistry, at the threshold of sensitivity used in this study, in a proportion of fibroblasts and endothelial cells in the lamina propria. In frictional keratosis there was also increased expression of p16 in basal and parabasal cells which may be related to increased turnover rates. The unexpected finding of p16 in cell nuclei in the parakeratinizing squamous may relate to cell senescence. Nuclear p16 expression has been described in adult but not fetal tissues in many organs (5) and in cells in culture reaching their limit of population doubling (15). Buajeeb et al. (16) have reported that p16 is not reliable for oral mucosal dysplasia and malignant transformation, although it is possible that p16 plays a role in cell senescence in normal oral mucosa since the protein is detectable by Western blotting in normal oral mucosa (3). Sousa et al. (17) have reported that no significant statistical difference of the cell proliferation rate between oral lichen planus and epithelial dysplasia $(p>0.05)$ and between the epithelial dysplasia and oral squamous cell carcinoma $(\mathrm{p}>0.05)$ was observed. Further studies using methods with greater sensitivity are required to evaluate this possibility. Santos et al (18) found that the most early alterations in oral leukoplakias are a significant increase of cell proliferation in mild and moderate dysplasias and an increased p53 over-expression.

In summary, nuclear p16 expression may be important in controlling cell proliferation following a stimulus such as hyperkeratosis or smoking. In addition to these short-term influences on cell proliferation, p16 expression may be involved in the long-term loss of proliferation in cell senescence of oral mucosa.

\section{References}

1. Wu CL, Roz L, McKown S, Sloan P, Read AP, Holland S, et al. DNA studies underestimate the major role of CDKN2A inactivation in oral and oropharyngeal squamous cell carcinomas. Genes Chromosomes Cancer. 1999;25:16-25.

2. Okami K, Reed AL, Cairns P, Koch WM, Westra WH, Wehage S, et al. Cyclin D1 amplification is independent of p16 inactivation in head and neck squamous cell carcinoma. Oncogene. 1999;18:3541-5. 3. Chen Q, Luo G, Li B, Samaranayake LP. Expression of p16 and CDK4 in oral premalignant lesions and oral squamous cell carcinomas: a semi-quantitative immunohistochemical study. J Oral Pathol Med. 1999;28:158-64.

4. Lai S, El-Naggar AK. Differential expression of key cell cycle genes (p16/cyclin D1/pRb) in head and neck squamous carcinomas. Lab Invest. 1999;79:255-60.

5. Nielsen GP, Stemmer-Rachamimov AO, Shaw J, Roy JE, Koh J, Louis DN. Immunohistochemical survey of p16INK4A expression in normal human adult and infant tissues. Lab Invest. 1999;79:1137-43. 6. Thomson PJ, Potten CS, Appleton DR. Mapping dynamic epithelial cell proliferative activity within the oral cavity of man: a new insight into carcinogenesis? Br J Oral Maxillofac Surg. 1999;37:377-83.

7. LaRue H, Allard P, Simoneau M, Normand C, Pfister C, Moore L, et al. $\mathrm{P} 53$ point mutations in initial superficial bladder cancer occur only in tumors from current or recent cigarette smokers. Carcinogenesis. 2000;21:101-6.

8. Thomson PJ, Potten CS, Appleton DR. Characterization of epithelial cell activity in patients with oral cancer. Br J Oral Maxillofac Surg. 1999;37:384-90.

9. Villablanca AC. Nicotine stimulates DNA synthesis and proliferation in vascular endothelial cells in vitro. J Appl Physiol. 1998;84:2089-98.

10. Waggoner SE, Wang X. Effect of nicotine on proliferation of normal, malignant, and human papillomavirus-transformed human cervical cells. Gynecol Oncol. 1994;55:91-5.

11. Piepkorn M. The expression of p16(INK4a), the product of a tumor suppressor gene for melanoma, is upregulated in human melanocytes by UVB irradiation. J Am Acad Dermatol. 2000;42:741-5.

12. Kato H, Yoshikawa M, Fukai Y, Tajima K, Masuda N, Tsukada K, et al. An immunohistochemical study of p16, pRb, p21 and p53 proteins in human esophageal cancers. Anticancer Res. 2000;20:345-9. 13. Suzuki H, Fujioka Y. Deletion of the p16 gene and microsatellite instability in carcinoma arising in pleomorphic adenoma of the parotid gland. Diagn Mol Pathol. 1998;7:224-31.

14. Chen M, Chen ZQ, Cui PG, Yao X, Li YM, Li AS, et al. The methylation pattern of p16INK4a gene promoter in psoriatic epidermis and its clinical significance. Br J Dermatol. 2008;158:987-93.

15. Zindy F, Quelle DE, Roussel MF, Sherr CJ. Expression of the p16INK4a tumor suppressor versus other INK4 family members during mouse development and aging. Oncogene. 1997;15:203-11.

16. Buajeeb W, Poomsawat S, Punyasingh J, Sanguansin S. Expression of p16 in oral cancer and premalignant lesions. J Oral Pathol Med. 2009;38:104-8.

17. de Sousa FA, Paradella TC, Carvalho YR, Rosa LE. Comparative analysis of cell proliferation ratio in oral lichen planus, epithelial dysplasia and oral squamous cell carcinoma. Med Oral Patol Oral Cir Bucal. 2009;14:e563-7.

18. Santos-García A, Abad-Hernández MM, Fonseca-Sánchez E, Cruz-Hernández JJ, Bullón-Sopelana A. Proteic expression of p53 and cellular proliferation in oral leukoplakias. Med Oral Patol Oral Cir Bucal. 2005;10:5-8;1-5. 